MATEC Web of Conferences 22,04007 (2015)

DOI: $10.1051 /$ matecconf/ 20152204007

(c) Owned by the authors, published by EDP Sciences, 2015

\title{
A comprehensive review of the process on hexachlorobenzene degradation
}

\author{
Xiyan Ji, Weidong Lin, Wudi Zhang*, Fang Yin, Xingling Zhao, Changmei Wang, Jing Liu, Hong Yang \\ \& Shiqing Liu \\ Yunnan Normal University, Kunming, Yunnan, China
}

\begin{abstract}
This paper describes the chemical, physical property of the pollution source along with its perniciousness. In addition, with the recent treatment or degradation of the hexachlorobenzene (HCB), it talks about the research developments on the HCB. Of the many options available for treatment of municipal and industrial HCB pollution, the anaerobic biological treatment process is unique because of its potential for producing usable energy. It focuses on the biodegradation pathway which is intent to finish the steps of dechlorination. Moreover, the future study on the HCB degradation is prospected in this paper from the author's angle.
\end{abstract}

Keywords: hexachlorobenzene; perniciousness; degradation; anaerobic; dechlorination

\section{INTRODUCTION}

$\mathrm{HCB}$, as a kind of notorious persistent organic pollutants whose abbreviation is called POPs, keeps the marvelous emission with $12000 \sim 92000 \mathrm{~kg}$, whose mean level is $23000 \mathrm{~kg}$, into the natural environment around the globe ${ }^{[1]}$. Compared with alkyl aromatic compounds, the chlorobenzene compounds, owing to the fact that chloride ions have high electronegativity, cause the benzene to become electrophobic, and with the increasing of the chlorine substituent, the activity of chlorobenzene compounds is reducing, contributing to its stability ${ }^{[2]}$. And for exactly that reason, the organochlorine pesticides have the nature of persistence, Semi-volatile, bioaccumulation and also highly toxicity ${ }^{[3]}$, and they have long-distance migration and sedimentation potential which will threaten the environment and health security of the ones who live nearby the pollution source ${ }^{[4]}$ this is an undeniable and unforgiving fact. In China, it is banned from preparing for pesticides but the producing of the HCB is still maintained, and the sodium pentachlorophenate and other related chemical products are mainly manufactured.

\section{PERNICIOUSNESS OF HCB}

\subsection{Water and sediment}

HCB water environment pollution comes mainly from the agricultural production process. Research Center for Eco-Environmental Sciences ${ }^{[5]}$ recommended the maximum of HCB is $0 \mathrm{mg} / \mathrm{L}$. However, in a large city in East China, the HCB concentrations in tap water and surface water, respectively, more than 170 -fold and 15 -fold, according to WHO criteria ${ }^{[6]}$. Yang Jiamo ${ }^{[6]}$ detected the HCB of the suspended solids in Yangtze water was found up to $9106 \mathrm{ng} / \mathrm{g}$.

*Corresponding author: wootichang@163.com
During the 1960s and 1980s, organochlorine pesticides were once widely used in the area in the agricultural production process. Pearl River is located in the subtropical zone, with abundant rainfall and runoff volume into the sea. In recent decades of large-scale development and utilization of land, pesticide residues have gone with rainfall, atmospheric deposition and in other ways to enter the Pearl River, leading to the pollution in Pearl River. A survey of the literature available shows that DDTs pesticide content in surface sediments of the Pearl River is $1.92 \sim 39.13 \mathrm{ng} \cdot \mathrm{g}^{-1}$ [7], and the content of $\mathrm{HCHs}$ pesticides in surface sediments is $1.42 \sim 3.80 \mathrm{ng} \cdot \mathrm{g}^{-1}[7]$.

\subsection{Soil}

In the petroleum, petrochemical, pesticide formulations, chemicals and other heavily polluting production sites, production can cause many kinds of harmful pollutants, such as HCB with large quantities, and gathered a large number of other toxic organic compounds and heavy metals discharged. All of these pollutants are deposited in the production sites, which form the soil adsorption in complex contaminated sites. Most of these pollutants present are landfilled which is the main treatment ${ }^{[8]}$. The study showed that the content of HCB in a certain chemical soil road is greater than $100 \mu \mathrm{g} / \mathrm{g}{ }^{[7]}$; and the content of $\mathrm{HCB}$ in the soil near the outfall of a chlor-alkali plant also reaches to $29 \mathrm{mg} \cdot \mathrm{kg}^{-1}$ [9]; the content of $\mathrm{HCB}$ in some chemical waste is relatively high, reaching 6000 $000 \mu \mathrm{g} \cdot \mathrm{kg}^{-1[10]}$.

\subsection{Atmosphere}

Chlorobenzenes not only deposited in the soil and water, but also in the atmosphere, OCPs in gaseous form adsorption proliferation and migration in the suspended particulate matter, lead to global pollution. 


\section{MATEC Web of Conferences}

In the past decades, the number of China's OCPs atmospheric monitoring reports has been increasing. The monitoring data of HCB and DDT is in Table $1^{[11]}$ $-[15]$.

Table1. Contents of HCB and DDT in China atmosphere

\begin{tabular}{lllll}
\hline Sample sites & Time & $\begin{array}{l}\mathbf{H C B} / \mathbf{n} \mathbf{g} \\
\boldsymbol{\bullet}^{-\mathbf{3}}\end{array}$ & $\begin{array}{l}\mathbf{D D T} / \mathbf{n} \mathbf{g} \\
\boldsymbol{\bullet}^{-\mathbf{3}}\end{array}$ & References \\
\hline Shenyang & 2009 & 18.97 & 42.27 & {$[11]$} \\
Guangzhou & 2006 & 109.01 & 131.14 & {$[12]$} \\
Chongming & 2007 & $0.38 \sim 2.26$ & $0.17 \sim 0.98$ & {$[13]$} \\
Island & & & & \\
Qomolangma & 2002 & 0.021 & 0.005 & {$[14]$} \\
Beijing & 2002 & 0.24 & 0.96 & {$[15]$} \\
\hline
\end{tabular}

\section{METHODS OF HCB DEGRADATION}

In recent years, there have been many researches on HCB degradation. In 2013, some scholars did experiment using different $\mathrm{PH}$, at different temperatures, and studying the impact of activated carbon fiber's adsorption of hexachlorobenzene. In 2010, another group of scholars adopted an ultrasonic instrument occurring with petroleum ether and acetone as the solvent extraction of three kinds of chlorinated volatile matter.

\subsection{Anaerobic microbial degradation of chloroben- zene}

Under anaerobic or anoxic conditions, the redox potential of environment is low; under the action of the enzyme on the benzene ring who has the low electron density in chlorobenzene, the reducing agent is susCeptible to lead nucleophilic attack, a chlorine atom is easily substituted, as a result showing the good biodegradability. Anaerobic degradation mechanism of chlorobenzene mainly means that chloride is replaced by hydrogen under enzymatic, generating a reaction that is called dechlorination.

United State Environmental Protection Administration (USEPA) did some estimation [1] about pesticide HCB's release from the production process, for example, the production of $1 \mathrm{~kg}$ of PCNB will release approximately $500 \mathrm{mg}$ (North America) or $1000 \mathrm{mg}$ (outside North America) of HCB.

In a word, HCB pollution comes mainly from the extensive use of pesticides in agriculture, industrial solid waste incineration, medical waste incineration, sewage sludge incineration, melting scrap metal, waste tires burning, waste oil combustion, cement manufacturing municipal sewage and sludge treatment process, chlorine bleach (paper) process, wood processing, sintering plants, and so on. Copper, aluminum, magnesium smelting and the incineration process can also generate the HCB.

Numerous studies showed that the bacteria which is isolated from digested sludge, river sediments, ditch sediment and soil in anaerobic environments, under the premise of glucose, formic acid, acetic acid and inorganic iron salts and other nutrients exist, is capable of degrading the $\mathrm{HCB}$, and it can be degraded into less toxic, more biodegradable low-chlorobenzene compounds (shown in Table 2).

\subsubsection{Anaerobic degradation pathways of $H C B$}

Most experts and scholars abroad not only studied on the anaerobic degradation of HCB, but also on degradation pathway of it, which is compared to Chinese researches only focusing on the situation about anaerobic degradation of HCB. Fathepure ${ }^{[26]}$ in 1988 firstly proposed possible degradation pathway of

Table 2. Anaerobic degradation of $\mathrm{HCB}$

\begin{tabular}{|c|c|c|c|c|c|}
\hline $\begin{array}{ll}\begin{array}{l}\text { Sources } \\
\text { strain }\end{array} & \text { of } \\
\end{array}$ & $\begin{array}{l}\text { Kinds } \\
\text { of strain }\end{array}$ & $\begin{array}{l}\text { Electron donor / Nutri- } \\
\text { ent }\end{array}$ & Ultimate product & $\begin{array}{l}\text { Degradation rate } \\
/ \%\end{array}$ & References \\
\hline \multirow[t]{8}{*}{ Digested sludge } & $\begin{array}{l}\text { Mixed } \\
\text { strains }\end{array}$ & $\begin{array}{l}\text { Glucose, Formic acid, } \\
\text { Ethanoic acid, Propionic } \\
\text { acid, Butyric acid }\end{array}$ & & $30-60$ & [16] \\
\hline & & Glucose, Vitamin $B_{12}$ & & $40-70$ & [17] \\
\hline & & $\mathrm{Fe}^{3+}$ & & $15-100$ & [18] \\
\hline & & $\begin{array}{lll}\begin{array}{l}\text { Glucose, } \\
\text { vitamin } \mathrm{B}_{12}\end{array} & \mathrm{Fe}^{2+}, & \mathrm{Fe}^{3+}, \\
\end{array}$ & & $23-96$ & [19] \\
\hline & & & $\begin{array}{l}\text { 1,2-dichlorobenzene } 1,4- \\
\text { dichlorobenzene }\end{array}$ & 100 & [20] \\
\hline & & & $\begin{array}{l}\text { 1,3,5-trichlorobenzene1,2- } \\
\text { dichlorobenzene }\end{array}$ & 95 & [21] \\
\hline & & & $\begin{array}{l}\text { 1,4-dichlorobenzene } 1,3- \\
\text { dichlorobenzene }\end{array}$ & & [22] \\
\hline & & $\mathrm{C}_{3} \mathrm{H}_{3} \mathrm{NaO}_{3}$ & & 59.4 & [23] \\
\hline \multirow[t]{2}{*}{ River sediments } & $\begin{array}{l}\text { Mixed } \\
\text { strains }\end{array}$ & $\begin{array}{l}\text { Glucose, } \\
\mathrm{FeSO}_{4} \cdot 7 \mathrm{H}_{2} \mathrm{O}\end{array}$ & & $75-100$ & [24] \\
\hline & & Glucose, Acetate & Trichlorobenzene & $40-55$ & [25] \\
\hline
\end{tabular}




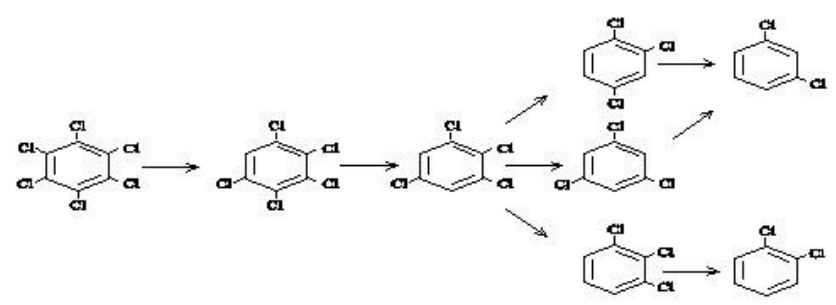

(a) Degradation pathway 1
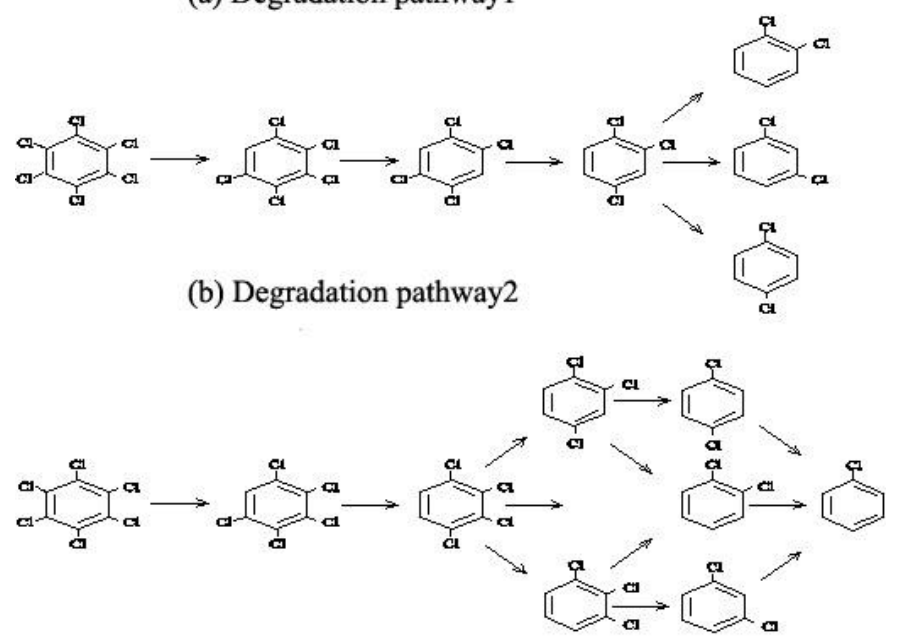

(c) Degradation pathway3

Figure1. Degradation pathway of $\mathrm{HCB}$

HCB. They used indigenous flora of digested sludge sewage in treatment plant to deal with the $\mathrm{HCB}$, and after 14 weeks, the HCB was completely converted to low-chlorobenzene compounds. The process was carried out by gradual dechlorination, and pentachlorobenzene and tetrachlorobenzenes were just intermediates of the degradation. So, Fathepure thought the degradation of HCB has three paths, which respectively are shown in Figure 1. In the third degradation mechanism, there is no accumulation of trichlorobenzene and dichlorobenzene, and all the HCB are converted into $\mathrm{MCB}$.

\section{PROSPECTS}

HCB is more suitable for microbial degradation under anaerobic conditions. Bacteria isolated from long-term contamination of the environment medium by HCB or long-term anaerobic environment can be even more effective on degrading the HCB. Cell types, nutrients and environmental factors, to a certain extent, affect the HCB anaerobic degradation rate. Compared with the aerobic degradation, anaerobic conditions meet the HCB degradation requests more easily, with the advantages such as simple experimental operation, low repair costs, and easier to implement engineering applications.

HCB is generally remained in the complex natural environment in soil, water, sediment, coexisting with a variety of microorganisms. Degrading bacteria obtained in the laboratory, whereas, under the environmental conditions above is often unable to survive or fail to meet the expectations. Therefore, how to train a domesticated laboratory strains used in practical good governance of HCB contamination is a problem to be solved at present, which is also the key to governing HCB remediation of contaminated sites. In short, HCB anaerobic degradation is a key concern research.

\section{ACKNOWLEDGEMENTS}

This work was financially supported by the Science and Technology Condition Platform Construction Projects of Yunnan (2013DH041); Specialized Research Fund for the Doctoral Program of Higher Education of China (20135303110001); Natural Science Foundation of China (51366015); Applied basic research fund key projects in Yunnan province (2014FA030).

\section{REFERENCES}

[1] Bailey R E. 2001. Global hexachlorobenzene emissions Chemosphere, 43(2): 167- 182.

[2] Wang Y F, Zhang Z M. \& Hu X M. 2006. The research progress on the treatment for chlorobenzene in the 


\section{MATEC Web of Conferences}

wastewater. Industry Safety and Environmental Protection, 32(3): 37-40

[3] Lyon. 1991. International Agency for Research on Cancer. Monographs on the Evaluation of Carcinogenic Risks to Humans. pp: 43-53.

[4] Yu G, Niu J F. \& Huang J, et al. 2005. Persistent Organic Pollutants: the New Global Environmental Problem. Beijing: Science Press, pp: 91-105.

[5] Barry G, Oliver. \& Karen D Nicol. 1982. Chlorobenzenes in sediments, water and selected fish from Lakes Superior, Huson, Erie and Ontario. Environmental Science Technology, (16): 532-536.

[6] Yang J M, Wang Y. \& Su Q Q et al. 2004. Investigation of organochlroine pesticides residue in the suspended solid of Wuhan section of the Yangtze River. Research of Environmental Science, 17(6): 27-29+38.

[7] Tian H Z, Wang L. \& Gao L R, et al. 2013. Distribution of organochlorine pesticides (OCPs) in the surface sediments of Zhujiang River. Environmental Chemistry, 32(2): 225-231

[8] Nie X Q, Liu J G. \& Zeng X W at al. 2013. Solidification stabilization of hexachlorobenzene polluted soils. Journal Tsinghua University (Sci \&Tech), 53(1): 84-89.

[9] Cleemanna M, Rigetb U F. \& Paulsena G B, et al. 2000 Organochlorines in Greenland marine fish, mussels and sediments. Science of the Total Environment, 245: 87102.

[10] World Health Organization. 1986. Sanitary Standard for Drinking Water. Beijing: People's Health Press, pp 24-27.

[11] Shi J L. 2008. Aerosol in Guangzhou area of persistent organic pollutants and isotopic distribution of $7 \mathrm{Be}$ Qingdao.

[12]Zhu X H, Yang Y L. \& Lu G H, et al. 2010. The pollution and environmental behaviors of HCHs, DDTs at air/soil interface in Chongming Island. Journal of Agro-Environment Sciences, 29(3): 444 - 450.

[13]Li J, Zhu T. \& Wang F, et al. 2006. Observation of Organochlorine Pesticides in the air of the Mt. Everest region. Ecotox Environ Safety, 63(1): 33 - 41.

[14] Wu S P, Cao J. \& Li B G, et al. 2003. Residues and distribution of organochlorine pesticides in airborne particles of different sides from urban areas. Research of Environmental Sciences, 16(4): 36-39.

[15]Tong Q, Feng S Y. \& Ruan Y Y, et al. 2000. Distribution of organchlorine pesticides on the different diametral atomospheric particulate. Environmental Chemistry, 19(4): 307-312.

[16]Sa R L, Yang X M. \& Jia X S. 2010. Impact of environmental factors on the anaerobic degradation capability of hexachlorobenzene. Ecology and Environmental Sciences, 19(5): 1030-1033.

[17] Sa R L, Qu T. \& Jia X S, et al. 2009. Study on cometabolic degradation of hexachl orobenzene under anaerobic mixed cultivation. Environmental Engineering, (27S).

[18] Jiang H L. 2007. A Study on Processing Conditions for Improving Biodegradation Activity of Hexachlorobenzene Co-metabolism by Domesticated Anaerobic Microoganisms. Guangzhou: Zhongshan University.
[19]Yuan S Y, Su C J. \& Chang B V. 1999. Microbia dechlofination of hexachlorobenzene in anaerobic sewage. Chemosphere, 38(5): 1015-1023.

[20]Fathepure B Z, Tiedje J M. \& Beyd S A. 1988. Reductive dechlorination of hexachlorbenzene to tri-and dichlorobenzenes in anaerobinc sewage sludge. Applied and Environment Microbiology, 54(2): 327-330.

[21] Hirano T, Ishida T. \& Oh K, et al. 2007. Biodegradation of chlordane and hexachlorobenzenes in river sediment Chemosphere, 67(3): 428-434.

[22] Wang S J, Quan C. \& Zhao H M, et al. 2002. The research on the influence of $\mathrm{Fe} 2+$ to anaerobic biodegradation of the sediments in the Liao River. Journal of Dalian University of Technology, 42(2): 181-185.

[23] Jia Q Z, Wang X. \& Li G J, et al. 2005. Kinetics of the anaerobic degradation of $\mathrm{HCB}$ and $\gamma-\mathrm{HCH}$ in Liaohe River sediment. China Environmental Science, 25(S): 52-55.

[24]Chen Z L, Cai X M. \& Zhang W J, et al. 2006. Study on screening of hexachlorobenzene anaerobic degrading bacteria and their degradation capability. Journal of China Three Gorges University (Natural Science), 28(6): 548-551.

[25]Fathepuer B Z. \& Tiedje J M, Beyd S A. 1988. Reductive dechlorination of hexachlorobenzene to tri-and dichlorobenzenes in anaerobic sewage sludge. Applied and Environment Microbiology, 54(2): 324-330. 